\title{
Influence and Application of Cloud Logistics Mode on Express Service
}

\author{
Guangshu Xu, Xuewen Zhang \\ Logistics Institute, Beijing Wuzi University, Beijing, China \\ Email: 15202284246@163.com
}

Received 26 July 2016; accepted 28 August 2016; published 31 August 2016

Copyright (C) 2016 by authors and Scientific Research Publishing Inc.

This work is licensed under the Creative Commons Attribution International License (CC BY).

http://creativecommons.org/licenses/by/4.0/

(c) (i) Open Access

\begin{abstract}
In this paper, we first introduced the concept of cloud logistics, described the current status of the express delivery and analyzed the impacts of introducing cloud logistics on China's express delivery industry. Then based on the case of Stars Express, how to introduce the cloud logistics model to the express industry was discussed. Finally, a new model of cloud logistics platform was constructed.
\end{abstract}

Keywords

Cloud Logistics, Express Delivery, Stars Express

\section{Introduction}

In recent years, the development of Chinese express delivery is extremely rapid. In 2015, Chinese express delivery volume, more than 20 billion, is 100 times of 2005, and the average annual growth rate is nearly $40 \%$. There are a lot of problems during the development of Chinese express delivery companies. Firstly, express delivery companies do not distinguish the distribution of goods. Secondly, the courier industry is very difficult to guarantee the standard in goods distribution. Last but not least, under the current situation, the courier companies enter the threshold lower than foreign country, which leads to a high rate of damage in distribution process.

The cloud logistics is a way to save the cost of logistics for the courier companies. Cloud logistics information platform is like a large pool. The supplier is "the supplier of the large pool", the customer is "the tap of the large pool". When the customers need services, they only need to open the "faucet", and it will meet customers' requirements. However, how to apply the cloud logistics platform is still a major problem in the actual delivery companies. Through the research of this paper, I hope to provide some help for the application of cloud logistics platform in express delivery industry. 


\section{Overview of Cloud Logistics and Express Delivery Industry}

Cloud logistics is based on cloud computing environment, which is contains a lot of different characteristics. The impact of cloud logistics on the courier industry is very huge, and if we can apply to the cloud logistics industry to the specific delivery, it will be express cross-age significance.

\subsection{Overview of Cloud Logistics}

Since the reform and opening up to the outside world, Chinese logistics industry is developing rapidly, in 2013, China's express delivery industry (International) on the development of the General Assembly State Post Bureau Liu Jun, deputy director of the introduction, in recent years, China's express delivery services will get long-term development, from 2006 to 2012, years Express handling capacity by 10 billion increase to 57 billion, the average growth rate of $33 \%$, amount of treatment was the highest in a day more than 30 million pieces. Related data show that China's express delivery industry accounted for $0.3 \%$ of the proportion of GDP, while the proportion of foreign countries is $1 \%$ [1]. These data show that as long as the management of the courier industry is reasonable and scientific, its development speed will be very fast. On the other hand, it is hardly to meet the growing of people's material and cultural needs under the current logistics situation.

\subsubsection{Definition of Cloud Logistics}

Cloud logistics is a cloud platform, all of the logistics company, agent service providers, equipment manufacturers, industry associations, regulatory agencies, industry, media, legal structure and so focused on cloud integration into resource pools, various resources and interact with each other to show, on-demand communication, reach intention to reduce costs and improve efficiency [2]. As Chen Ping made a metaphor in the cloud logistics, the whole logistics industry is like a huge running water system, which includes a large pool, a tap water pipe and taps. In this system, the huge pool is equivalent to the fourth party logistics, the water supply pipeline is equivalent to railways, highways, waterways, aviation and pipeline transportation companies, the faucet is equivalent to a variety of distribution companies. Cloud logistics will gather all the orders in the big pool (i.e. cloud logistics platform). Through the "big pond", these orders will be classified according to time and place. Then these orders will be by specific transport companies assigned to the courier company, at last to the customers.

According to the current situation of China, integrated cloud computing, SaaS (Software as a service) and other related technologies, the basic framework of the cloud logistics platform is shown in Figure 1.

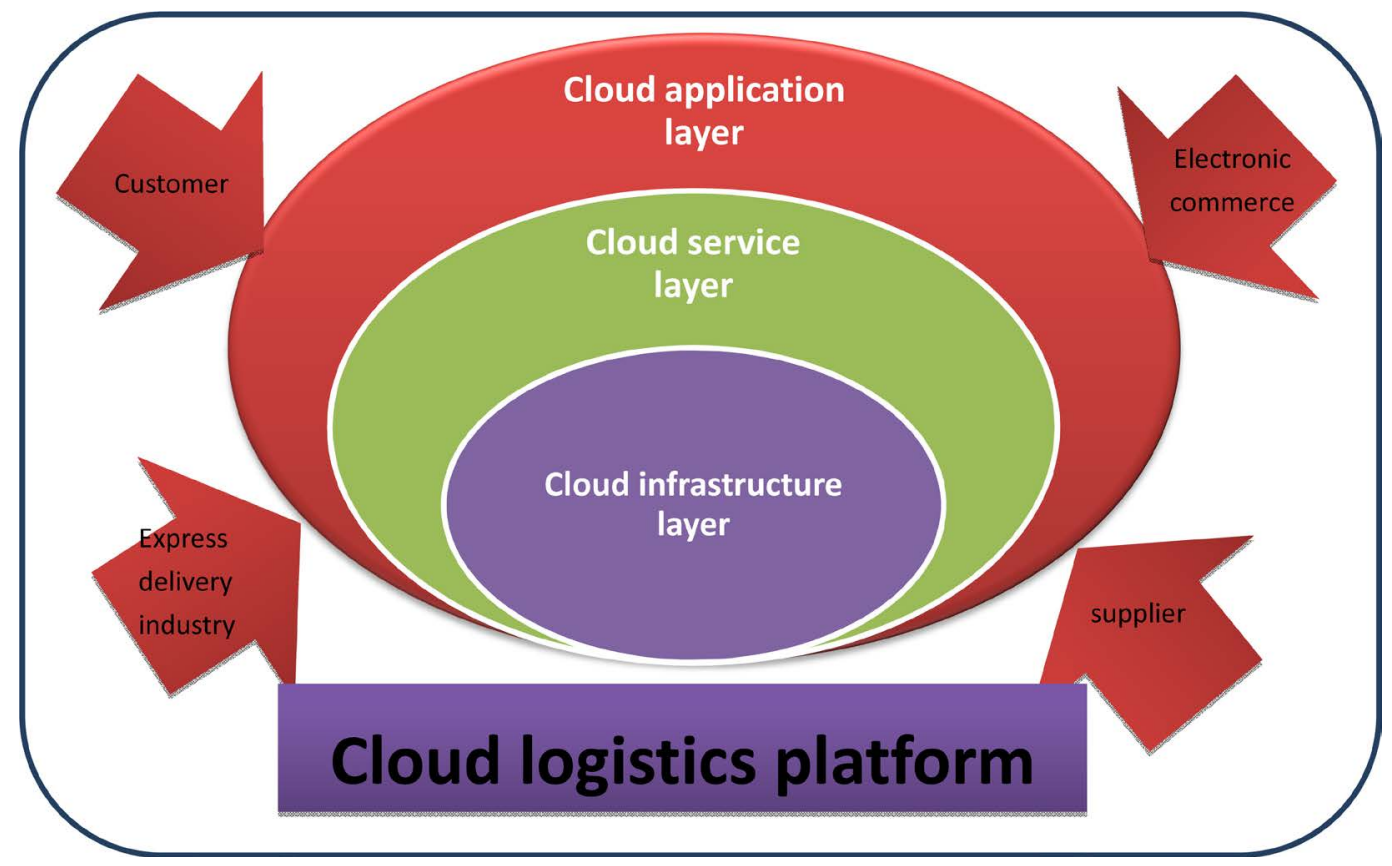

Figure 1. Cloud logistics information platform design. 


\subsubsection{Characteristics of Cloud Logistics}

1) Socialization

Cloud logistics will promote the construction of tens of thousands of courier companies, on behalf of the delivery point, the establishment of distribution points, when the logistics and distribution will be more convenient and timely. Customers only need to choose the nearest receiving point to receive their own courier. And a large number of express outlets increased the flexibility of sending and receiving. Cloud logistics platform can make full use of the social resources.

2) Saving

Each courier company has a small cloud computing platform, this situation is not only to express the company's funds to form a big test, but also the formation indicated a waste of social resources. Focus on building a large cloud logistics platform, the need for information, only need to pay the cost of the corresponding module, you can get timely information, and the information obtained is more timely and broad. In this way, through the cloud logistics platform, society can save energy, enterprises can save money.

3) Standardization

That the development of the courier companies are not the same as our country's express delivery industry is a very serious problem. This phenomenon caused by the courier companies get a different amount of information, access to information for a large proportion of different time.

Cloud logistics is a common access and filtering information on a shared platform, so it can greatly promote the process of standardization of China's express delivery industry.

\subsection{Overview of Express Industry}

From the beginning of 1990s, with the reform and opening up, China's express delivery industry after 20 years of development has made great progress.

\subsubsection{Development Status of China's Express Delivery Industry}

1) The rapid growth of the express market

According to the China Statistical Yearbook, China's express delivery handling capacity in 2007, China Express annual handling capacity of 1.2 billion, in 2010 for 2.3 billion, to 2014, China's express delivery business quantity for 13.9 billion pieces. From 2007 to 2014, the annual handling capacity increased by nearly 12 times, as shown in Table 1.

2) Develop significantly in some regions

At present, China's express layout has been formed in a part of second tier cities as the center of the regional express service area, each courier service area and the surrounding radiation to drive the development of the surrounding courier industry. Some more developed cities have become the center of the regional express industry. Chinese express industry formed a framework based on circle.

\subsubsection{The Operation Mode of Express Industry in China}

China has formed three types of state-owned, private, foreign competition pattern. According to the 2011 postal

Table 1. 2007-2014 Chinese express business income, the annual handling capacity.

\begin{tabular}{ccccc}
\hline year & $\begin{array}{c}\text { Express } \\
\text { (million pieces) }\end{array}$ & $\begin{array}{c}\text { Express service revenue } \\
\text { (million yuan) }\end{array}$ & $\begin{array}{c}\text { The growth rate of annual } \\
\text { processing volume \% }\end{array}$ & $\begin{array}{c}\text { Growth rate of } \\
\text { business income \% }\end{array}$ \\
\hline 2007 & 1201.89 & $34,258.51$ & 0.26 & 0.19 \\
2008 & 1513.29 & $40,842.74$ & 0.23 & 0.17 \\
2009 & 1857.85 & $47,900.30$ & 0.26 & 0.20 \\
2010 & 2338.92 & $57,460.29$ & 0.57 & 0.32 \\
2011 & 3673.11 & $75,798.78$ & 0.55 & 0.39 \\
2012 & 5685.48 & $105,533.24$ & 0.55 & 0.39 \\
2013 & 9186.74 & $144,168.15$ & 0.61 & 0.37 \\
\hline
\end{tabular}


industry development statistics bulletin "shows that, 2011 years of private enterprises in express handling capacity was 24.8 billion yuan, accounting for the total market $67.6 \%$, courier business income of 37.45 billion yuan, accounting for $49.4 \%$ market share of income; state-owned enterprises years Express processing capacity of 10.8 billion Yuan, representing the city field $29.4 \%$ of the total, courier business income for 2711 million yuan, accounting for $35.8 \%$ of the income share of the market; foreign express delivery companies in express processing capacity for 1.1 billion, accounting for of the total market 3.0\%, courier business income to 112.5 million yuan, accounting for 14.8 percent of the market share of income [3]. From the data can be seen, private enterprises accounted for the vast majority.

In the private express industry, its operating mode is diverse, mainly can be divided into: franchise, own operation, mixed operation management (franchise, own operation, agent) three ways. In these models, "SF" is the representative of the own operation model. "ZJS express" is mainly rely on the own operation model, agent and franchise for the comprehensive management mode of auxiliary. Other private courier companies are franchising, we are more familiar with five courier companies (ZTO, YTO, STO, YUNDA and Best Express) are grown by the way of franchising. Therefore, franchising is a major feature of China's express delivery industry, this model of express delivery companies, whether it is the market share or a number of enterprises are in a dominant position. Compared to the advantages as China's express delivery industry development mode-the franchise could not be ignored, it is the number of funds to the enterprise requirements are not very high and other operational mode of express business, and its rate of expansion is also relatively fast.

\section{The Impact of Cloud Logistics Model on Express Delivery Industry}

The establishment of cloud logistics model can bring a lot of convenience for the courier industries, which is conducive to the unification of logistics resources, to promote the standardization process of express delivery industry, and reduce the operation cost of express delivery industry.

\subsection{Help to Unify the Logistics Resources}

Chinese logistics operation as a whole is still in the traditional mode of operation, the overall level of service is uneven. There are a lot of problems restricting the rapid development of express enterprises. In the enterprise, "capital flow-information flow-logistics" chain communication urgently needs to be integrated and optimized. Cloud logistics model proposed, you can completely solve the courier industry in the three flow communication is not timely problem. Cloud logistics is the operation of the customer as the ultimate buyer, the supplier as the ultimate seller, the overall formation of the "seller-cloud logistics information service platform-the buyer" a big framework. E-commerce enterprises, express delivery companies, etc. can be through the cloud logistics platform to obtain the information needed in a timely manner.

\subsection{To Promote the Standardization of the Formation of the Courier Industry}

Most of the rapid development of technology, operation results to achieve standardization based on industrial innovation on the results Express delivery enterprises to achieve a qualitative leap, it is to meet the information dissemination in the courier industry, capital flows, the standardization of the operation of goods transport. According to the state has promulgated the "postal industry standardization" Twelfth Five Year "development plan", in the "Twelfth Five Year Plan" period, the State Post Bureau will develop and as soon as possible the implementation of e-commerce logistics courier services, fees and service standards of value-added services. Actively promote the delivery service and manufacturing, e-commerce and other related industries docking, to build a personalized, multi variety service delivery system [4]. Through the development and implementation of these standards to further improve the courier industry, the courier industry will be the establishment of cloud logistics information platform to build a solid foundation.

\subsection{To Reduce the Operating Costs of Courier Industry}

The cost control is very important in the enterprise, the original logistics operation link, express enterprise capital flow, information flow, logistics flow process, there are a lot of unnecessary links.

Cloud logistics information platform can reduce the operating costs of enterprises from various directions. On the one hand, through the cloud of logistics information platform, enterprise to need the information sector to 
pay can obtain timely service, to avoid the access to necessary information and a waste of money, and at the end of a cloud of logistics information platform, access to information, you can get comprehensive and timely information service, compared to before the establishment of their own information service platform, information obtained to more comprehensive. On the other hand, cloud logistics information service platform can simplify the flow of goods. Cloud logistics information platform, the supplier is the ultimate seller, the customer is the ultimate buyer, supplier delivery through the cloud of logistics information platform, their nearest parcel distribution distance, receive task distribution, mass distribution. It also saves the running cost of distribution business.

\section{Application Research of Cloud Logistics Model of Express Industry—Stars Express as an Example Is Used in the Article}

In the express industry, Mr. Chen is the first one who proposed the concept of cloud logistics, in order to let their own theory is applied to the actual, in 2009 he founded the Stars Express, the initial investment is RMB 50 million yuan. On March 2011 Alibaba invest Stars Express seventy million yuan. In October of the same year, in order to company development rapid, Stars Express acquisitions Xin Feihong express company, and changed its name to "Stars Express Feihong”. They positioned themselves to provide real-time information and capital flows. In the platform, the customer is the ultimate buyer, supplier is the ultimate seller. The two sides can be traded according to information provided by the platform, the final completion of the settlement of funds in the platform. As of 2012, Stars Express have more than 3800 outlets, 28,100 employees, the average daily processing capacity of up to 230 thousand pieces express [5]. However, from March 2012, Stars Express because of capital chain problems caused collapse.

\subsection{Failure Analysis of Stars Express's Development of Cloud Logistics Mode}

In my opinion, Stars Express founded shortly after the industry downturn of the main reasons including joining the expansion speed too fast, the latter part of capital strand breaks, order sources are scarce and so on.

1) Alliance expansion speed too fast, the original determination principle could not be guaranteed.

Like most of the express delivery company, Stars Express is through franchise model to achieve the purpose of rapid expansion and network coverage in the country was 100\%. Stars Express joined the main distribution station for positioning, the franchise model is between join and direct. So soon join in mode, reduced to express an application to join the business investigation strictly, franchisee professional level of good and bad, this situation naturally leads to them with his early to determine the principle of drifting further and further away.

2) In the late period, the capital chain rupture and the operating system is too large.

The establishment and operation of cloud logistics platform need huge amounts of funds to do strong backing, Stars Express in the early by Ma's investment established cloud logistics platform, and put into operation, however, in the process of operation still need a lot of money to prop up. Although in choice franchisee, Stars Express received a lot of franchise fees, but for the operation of the logistics platform of cloud is still a drop in the bucket. At the same time, become Stars Express franchisees, most express is to choose cash on delivery. This is undoubtedly lengthening the chain of funds, the Stars Express entire operating system is undoubtedly one disaster after another.

3) The source of the order is scarce, and the express points are too detailed.

Stars Express in establishing their own cloud logistics platform, two positioning customer groups have failed, resulting their sources are scarce, and company has just started, then subdivision of each city in each region specific working position, which will undoubtedly increase the running a company into this, increases the possibility of funding strand breaks. All this will undoubtedly accelerate the pace of bankruptcy of the company.

\subsection{New Model of Cloud Logistics Platform}

Stars Express development cloud logistics platform, try running failure undoubtedly hindered the cloud logistics platform in the pace of development of our country, explains the development of express enterprises of our country is still not mature enough. The paper will be based on the current situation of our country, express delivery business process and the concept of cloud logistics to redesign the cloud logistics information platform, analysis of the process of cloud logistics information platform. 
What we wanted the cloud logistics main function is deal with large quantities of invoice and orders. First, customers choose the corresponding plate, cloud logistics platform through intelligent screening quickly choose out of the module, to achieve customer service needs. If the customers choose to customize the plate for a number of repeated services, cloud logistics platform needs to monitor the process, after the test run, the custom plate to adjust to the best operating conditions. Cloud logistics platform can be divided into three large plates to be designed, respectively: cloud application layer, cloud service layer, cloud infrastructure layer.

\subsubsection{Cloud Application Layer}

Cloud infrastructure layer (as shown in Figure 2) is the most basic aspect of cloud logistics platform, all business layer and the application layer of operation, have to rely on the infrastructure to support, infrastructure layer must have security software and hardware support. Hardware support is to ensure quality and safety of the computer, adequate stability of the network, capacity enough to ensure safe storage space and so on. Software support is to ensure the security of data communication, the timeliness of the sharing of resources, etc.

According to the theory of network running status and the related network and cloud infrastructure layer can be divided into three blocks: the virtualization infrastructure layer, is mainly composed of a variety of hardware and software resources; the second is according to the hardware resources, software resources to provide services and our national cyber security and development current situation, the logistics cloud is divided into three major types: public cloud and private and hybrid cloud; thirdly, based on the three classifications of logistics cloud, cloud application layer is divided into customer application, standard application and selection of application.

Logistics services can be divided into three main types: private cloud, public cloud and hybrid cloud. The cloud logistics service platform established in this article is based on hybrid cloud, private cloud and public cloud.

Cloud logistics platform service model is based on hybrid cloud causes are: Electronic Commerce in the development of our country is not very advanced, information leakage is inevitable, if you choose to use a public cloud and safe development of the company will have very big hidden trouble. Cloud logistics platform selection hybrid cloud, because it can run in the public cloud to information sharing of software and business operation in the enterprise with business software of sufficiently high degree of safety and effective link up. This program, not only can achieve the initial purpose of cloud logistics information sharing, but also to ensure the security of enterprise use of cloud logistics.

\subsubsection{Cloud Service Layer}

Cloud business layer (as shown in Figure 2) is the middle layer of cloud logistics platform, its main function is using cloud computing to provide meet the requirements of enterprise e-commerce and express industry, suppliers and the level mainly includes management of cloud services in cloud logistics platform positioning and cloud services. Among them, the positioning of the cloud services that customers through the cloud logistics platform requirements, or entrust their own cloud logistics platform for the relevant personnel to choose their own business requirements of the process of the plate. The management of cloud services is mainly responsible for the combination, arrangement, trial operation, debugging, operation and supervision of the selected software plate in the process of positioning. The cloud business layer can be divided into two layers: cloud services positioning and management of cloud services. The positioning of the cloud service is mainly to provide users with the service function of the logistics platform, which includes two aspects: one is to develop in line with the strategic planning of Enterprise Cloud logistics service platform, implementation of the corresponding enterprise specific services, which is to support enterprises in line with the company's own development unique design. Cloud services management is generally directly to customers, using SaaS (software as a service) to provide users with services.

\subsubsection{Cloud Infrastructure Layer}

The function of cloud application layer (as shown in Figure 2) is to provide effective, practical and innovative functions for the customers. With the general features: first, the user in the use of cloud services, only need to register an account in the corresponding port, through the audit, in accordance with the actual in the cloud logistics platform use pay to use; second, as long as it can and Internet connection, you could not limit the access they have paid the plate; third, we must have a very good ability to integrate information, be able to timely 


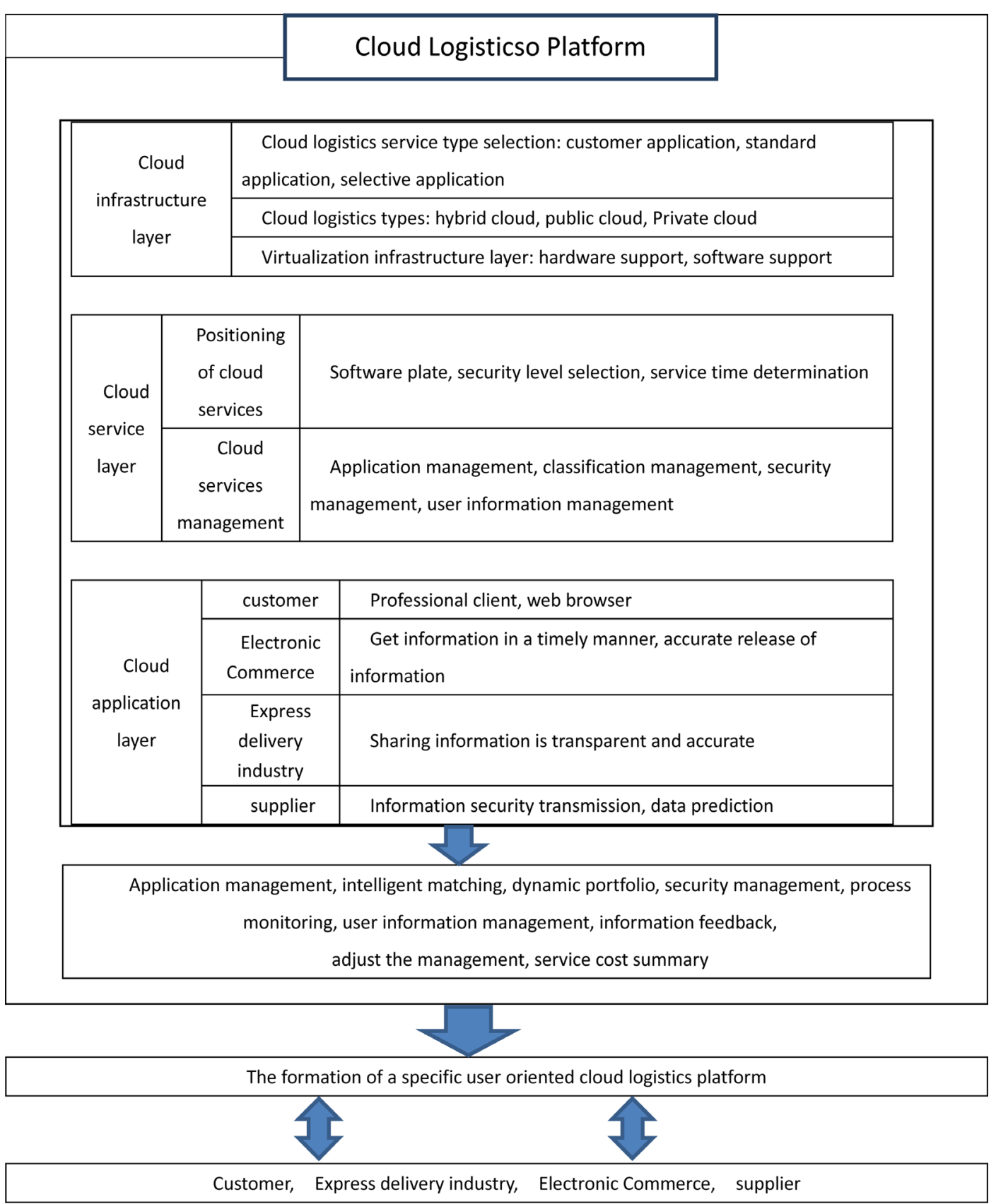

Figure 2. Schematic of each module function of cloud logistics platform.

integration of information from all aspects of the collection.

Cloud application layer is divided into four ports: customers, e-commerce, express delivery industry, suppliers. In the face of different ports, the corresponding service is different. Cloud application layer is divided into four ports: customers, e-commerce, express delivery industry, suppliers. In the face of different ports, the corresponding service is not the same. In customers, visit customers do is simple, convenient and should also ensure that customers use their own account, timely access to want to know the information, for example, determine the mail a package, the customer should be on the site accurately check to their own packages when where is expected when he arrived and other information. In e-commerce, so as to guarantee the security of information, because customers in the purchase of goods, is directly and e-commerce enterprises to communicate, if in the port information and the consequences will be unable to estimate. In the express industry, needs to achieve 
the accuracy of the information, customer in the mail a product, truly visible operation is the courier industry is they in the electronic commerce enterprise, supplier and customer contact together. So they are in the process of express products, be sure to timely release of relevant information in the cloud logistics platform for each time period. In supplier side, required to achieve information security guarantee by other criminals get the order to the supplier e-commerce business, vendor side should also with certain predictive software, you can up period in accordance with the order number, the commodity the pale busy season and probably predict e-commerce enterprises next order quantity.

\section{Conclusion}

This article, based on the analysis of the failure reasons of Stars Express, designs a new cloud logistics information exchange platform. In the new design of cloud logistics information exchange platform, the platform is divided into three layers: cloud application layer, cloud service layer, and cloud infrastructure layer. The combination of the three levels of cloud logistics platform will form a complete logistics information platform. Through the application of cloud logistics information platform in practice, it can not only promote the process of standardization of express delivery industry, but also save the logistics cost. Therefore, the application of cloud logistics information platform in the courier industry must be popular.

\section{References}

[1] Chang, L.Y. and Chen, H.Y. (2013) Study on the Future Development of China’s Private Express Delivery Industry. China Storage and Transportation, No. 11, 97-99.

[2] Wang, Q.F., Lv, H.B. and Jiang, Y. (2012) Study on the Structure and Application Mode of Cloud Logistics. Telecom Science, 28, 126-132.

[3] Xu, J.Y. (2013) Development Status and Strategies of China's Express Delivery Industry. Journal of Hubei University of Economics: Humanities and Social Sciences Edition, 10, 38-39.

[4] Chen, X.Q. (2012) Research on the Model of Cloud Logistics in the Private Express Industry Based on the Long Tail Theory. Southeast Academy of Science, No. 6, 79-87.

[5] Wen, Y.D. and Hou, J. (2013) From a Case of the Stars Express Discuss the Development of Cloud Logistics Mode. Containerization Combined, 24, 18-21.

Submit or recommend next manuscript to SCIRP and we will provide best service for you:

Accepting pre-submission inquiries through Email, Facebook, LinkedIn, Twitter, etc.

A wide selection of journals (inclusive of 9 subjects, more than 200 journals)

Providing 24-hour high-quality service

User-friendly online submission system

Fair and swift peer-review system

Efficient typesetting and proofreading procedure

Display of the result of downloads and visits, as well as the number of cited articles

Maximum dissemination of your research work

Submit your manuscript at: http://papersubmission.scirp.org/ 